\title{
PAYMENT FOR ENVIRONMENTAL SERVICES FOR THE SUSTAINABLE DEVELOPMENT OF THE TERRITORY
}

\author{
Anna Maria Di Trapani, Riccardo Squatrito, Mario Foderà, \\ Riccardo Testa, Salvatore Tudisca and Filippo Sgroi \\ Department of Agricultural and Forestry Sciences, University of Palermo, Italy
}

Received 2014-09-03; Revised 2014-09-15; Accepted 2014-09-17

\begin{abstract}
Over the last years the interest in environmental services provided by forests has considerably grow. This situation, in developed countries, derive from rising demand of new goods and services tied to landscape use and leisure activities. These can be considered such as no woody products and they represent externalities produced by forest that, if suitably utilized, could produce value for the area and earnings for people living near forests. From an economic point of view, at the aim of providing these services, it is necessary the introduction of a suitable payment system or, in alternative, a situation in which positive externalities of landscape, in sync with other goods/services, are offered to consumers. In this context, forest conservation and management assume a very important role, especially when public administration allocates decreasing funds to environment resources. In this paper it has been analyzed how positive externalities provided from forest, by means of an appropriate payment system and considering the integration with surrounding area, can contribute to the value creation.
\end{abstract}

Keywords: Payment for Environmental Services, Forest, Multifunctionality, Biodiversity

\section{INTRODUCTION}

According to forest multifunctionality, considered at the basis of modern forest planning and management, each forest stand fulfills all the functions attributable to a gen-eral forestry system, even if in different measures.

From an environmental point of view, forests carry out various ecosystem services corresponding to multiple benefits provided to humankind and, ultimately, to connections existing between environmental resources, economic systems and the human being (Monarca et al., 2009; Tudisca et al., 2014a; 2014b; 2014c; 2014d; Tomao et al., 2013).

With regard to socioeconomic perspectives, forest exploitation produces resources, guaranteeing at the same time a wide set of goods and services that range from wood products to no wood ones.

Services provided by forestry systems have already been well studied and demonstrated (Campbell and Tilley, 2014; Zanchi et al., 2014; Cudlìn et al., 2013).
Forests present numerous habitat to plants, animals and microorganisms, housing the majority of specie and contributing to preserve environmental stability in terms of biodiversity (Fedrowitz et al., 2014; Marshalek et al., 2014).

Furthermore, they play a key role in climate change mitigation through carbon capture and storage (Ximenes et al., 2012; Klein et al., 2013; Liu and Yin, 2013).

Paying attention to the interaction with water resources, forest functions include the protection of water quality and supply, the prevention of floods and landslides, the mitigation of drought effects and the struggle against soil erosion (Ferretti et al., 2014).

Among cultural services offered by forests, the possibility to experience landscapes that are largely undisturbed by human pressure and the role of state and national parks, aimed at facilitating environmental education and sustainable tourism, have to be highlighted (Brandt et al., 2014).

Corresponding Author: Filippo Sgroi, Department of Agricultural and Forestry Sciences, University of Palermo, Italy 
At the same time, forest management has an important economic role in many countries and they represent the starting point of new local economies in many rural areas, tied to their utilization both for recreational, cultural and touristic keys and for energetic production by bio-mass (Testa et al., 2014a).

In this way, forests could represent a source of employment, especially in rural zones where multifunctionality is achieved just by a sustainable utilization of forest resources, becoming a fundamental condition for human staying on the area (Mammuccini, 2004).

Forests are considered an important resource for socio-economic growth of mountain area but often they have been place of tension because of different interests between tourist development and environmental safeguard. Thus, new management instrument are required at the aim of conciliating various requirements (SISEF, 2014).

In fact, over the last years human activities have deter-mined huge impacts on ecosystems,

influencing their capability to generate services and externalities (TEEB, 2014).

In planning processes forest should be considered such as one of territorial components able to have a confrontation with other factors and processes involved in area management. Forests represent an important opportunity of economic growth and sustainable business development, constituting the base of an economic system founded on the production of ecofriendly goods and ecosystem services.

Goods, services and externalities contribute to the definition of ecosystem services, but they differ substantially because of market do not recognize the price of externalities that are free enjoyed from community (Pearce and Turner, 1989).

Externalities are defined as effects occurring every time that an economic activity of production or consumption affects utility levels of producers or consumers, whose effects are not evaluated or compensated (Dasgupta and Pearce, 1975). Externalities are positive if generated effects increase utility, while they are negative in the opposite case.

New earnings opportunity would occur for forest enterprise by the introduction of externalities in instruments for direct or indirect remuneration.

Forest produces various goods and services for many people, starting from individual citizen up to the whole community. Nowadays, it is necessary to set public policies able to identify the uses that maximized, in a sustainable way, net social benefits, including that ones deriving from no woody goods.

Economic laws show unequivocally that without public policies forest management leads to the no sustainability, the underestimation of good and service values without any market price and, ultimately, to the utilization of natural resources beyond reproduction capacity (Castellucci and Delfini, 2006).

Over a period of economic recession, in which public administration allocates decreasing founds managing forests, it is necessary to create alternative models that safeguard public goods.

In the present paper, after defining payment for environmental services (PES), Bosco Ficuzza, localized in hillmountain Palermo area, has been take into account.

Later reserve description, PES have been studied for detected area. Ultimately, by attributing specific scores, PES results have been showed, highlighting possible improvement in Bosco Ficuzza.

\section{PAYMENT FOR ENVIRONMENTAL SERVICES}

Human welfare depends on ecosystems and benefits that they provide (Costanza et al., 1997).

Externalities related to forest resources play an important role in their economic, as a natural consequence of the growing gap between the demand for public goods (water availability, air quality, landscape and biodiversity protection) and supply of goods and services generated by forests.

The cultural development and increased environmental awareness of the community bring out the role of forest ecosystems, including those in urban and suburban areas, such as public goods.

This role appears by a growing trend of users, an increase in the management complexity aimed at enhancing the multifunctionality and an acknowledgment of new socio-economic and ethical values, all within a framework that ensures their sustainable development (Yan and Tian, 2014; Kenneth et al., 1999).

The Ecosystem Services (ES) are defined as the benefits that derive directly or indirectly from ecosystems (MEA, 2005). The agroforestry area plays a complex role respect to ES. In fact, if on one hand its production proc-esses use the ES generated from the surrounding area, on the other hand it can provide ES to society. 
The biophysical quantification and monetary valuation of services allow to define and plan the public intervention, with particular attention to the agricultural and environmental policies aimed at biodiversity conservation.

Studies (Deal et al., 2012; Pettenella, 2011; Pirard et al., 2010) have analyzed the possibility of adopting new tools based on the creation of markets for specific goods or forestry services, in order to stimulate the offer, the socalled payment for environmental services.

PES are instruments created at the aim of correcting "market failures", associated with the traditional mode of offering of environmental goods and services (Pirard, 2012; Gómez-Baggethun and Ruiz-Pérez, 2011), stimulating the production of positive environmental externalities and transforming them into real products sold on the market (Vidale et al., 2012).

Wunder (2014) defines PES as a "voluntary transaction where a defined ES is bought by a purchaser who receives by a supplier of ES, on condition that the supplier ensures the supply of ES", in order to create contacts for PES. According to this, five conditions must be respect:

1) identification of a well defined environmental service to exchange;

2) presence of at least one buyer;

3) presence of at least one seller;

4) voluntariness between the parties to commercialize an environmental service;

5) conditionality of the payment, according to which producer is obliged to ensure environmental service over the time.

The creation of the PES comes from the need to improve effectiveness, efficiency and distributive equity in the production of a particular environment service, compared to a reference base level.

The PES schemes differ in scale, starting from small local initiatives up to global international agreements.

Furthermore, the number and institutional form of buy-ers, intermediaries and ES suppliers vary (i.e. individual landowners, communities, private companies, public administration). Other differences can be observe in the technical specifications of the ES and land use and the mechanisms used raising and distributing funds from buyers to suppliers.

The amount of money to be paid to service providers should be established by negotiation between buyers (for small scale PES) or by an intermediary institution (for large scale PES) Payments should cover at least the cost of perceived opportunity, but should not exceed the social value of the incremental environmental service provided (Prokofieva et al., 2014).

Under certain conditions, the willingness to pay can create financial incentives for local stakeholders at the aim of transforming the value of natural resources into goods and services (Muradian et al., 2010; Turner et al., 2003).

When the willingness to pay is formalized and is reflected in a PES, environmental services can be introduced to the markets in which they are not normally available.

\section{CASE STUDY}

The case study analyzes the Natural Reserve of Bosco Ficuzza. Bosco Ficuzza is currently the largest wooded complex in Western Sicily and it has become Natural Reserve (NR) since July 2000 under the name "Bosco Ficuzza, Rocca Busambra, Bosco del Cappelliere, Gorgo del Drago" (Gianguzzi and La Mantia, 2004). It is local-ized on an area of 7,397.49 hectares, of which 5,333.09 hectares represent the reserve and 2,064.40 hectares the pre-reserve (a controlled development area in order to integrate the surrounding zone with the reserve). Bosco Ficuzza extents in Corleone, Godrano, Marineo, Mezzojuso and Monreale municipalities (Fig. 1).

In addition to forestry-pastoral activity, vineyards and olive groves are cultivated and livestock farms are present.

The NR has a vertical drop of $1,079 \mathrm{~m}$, included between $534 \mathrm{~m}$ above sea level (a.s.l) located in the Mezzojuso territory and $1,613 \mathrm{~m}$ a.s.l of Rocca Busambra. The wooded area shows different weather conditions as a function of altitude and slope exposure. It is present a Mediterranean climate, characterized by hot and dry summer and rainy winter (Agnese et al., 2008; D'Asaro et al., 2014; 2012; Di Trapani et al., 2014; Grillone et al., 2014; 2012; 2009; Sgroi et al., 2014a).

The NR, thanks to its intrinsic peculiarities, offers numerous habitat, which are reflected in the flora and vegetation variety.

The biodiversity of the reserve is determined by the interaction between different topography, soil and climate conditions and reserve has several plant species (Federico, 2009). 


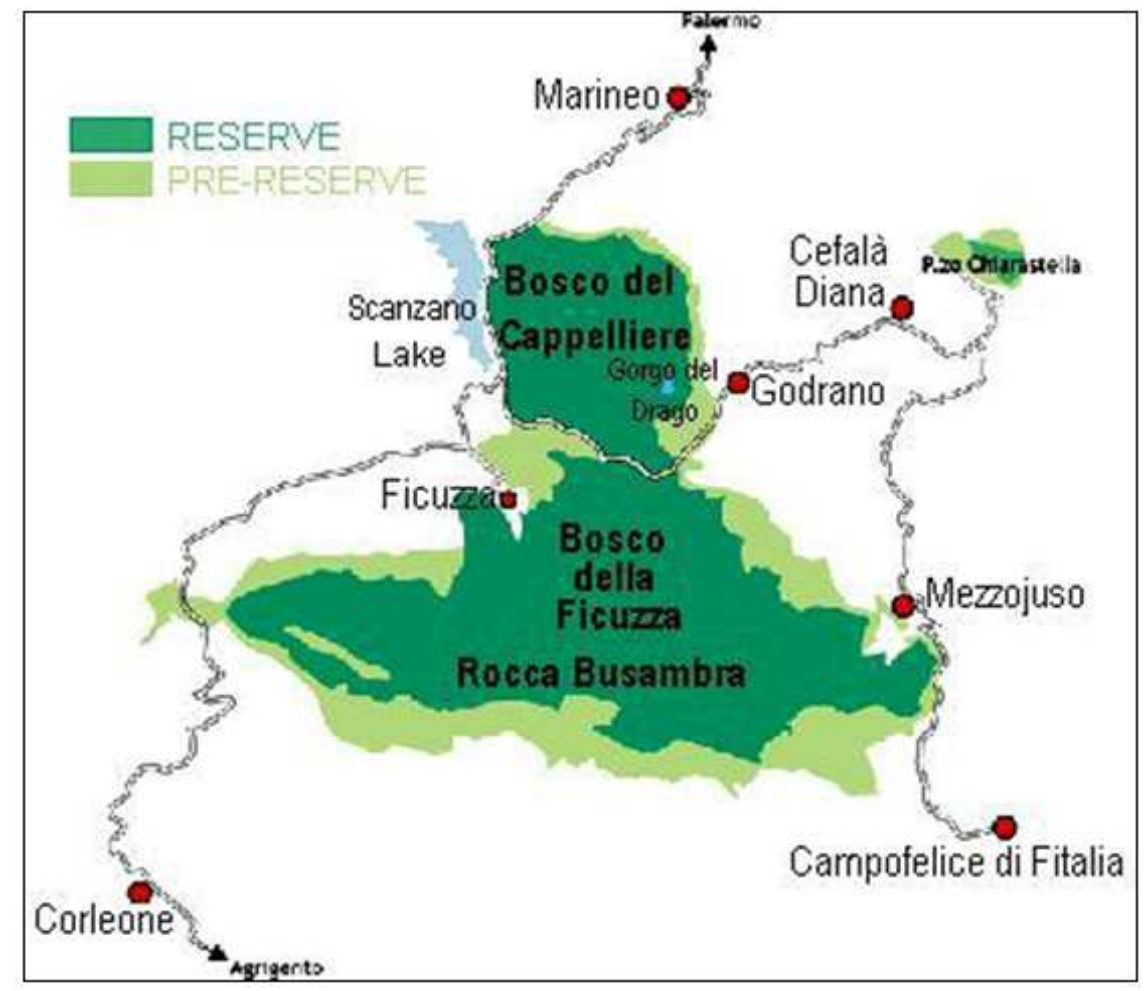

Fig. 1. Bosco ficuzza natural reserve area

Among Quercus species, are present the holm oak (Quercus ilex), the cork oak (Quercus suber), the downy oak (Quercus pubescens) and the endemic Gussone mossy oak (Quercus gussonei).

Other tree species are the ash (Fraxinus excelsior), the field maple (Acer campestre), the chestnut (Castanea sativa) and the Sicilian hackberry (Celtis asperrima).

The shrubby vegetation is represented by the hawthorn (Crataegus monogyna), the butcher's broom (Ruscus aculeatus), the honeysuckle (Lonicera caprifolium), the thorny asparagus (Asparagus acutifolius), the St. John rose (Rosa sempervirens), the tree heather (Erica arbo-rea) and the spiny broom (Calicotome spinosa).

The main herbaceous species are the spring cyclamen (Cyclamen repandum), the peony (Paeonia mascula), the Sicilian iris (Iris pseudopumila) and Tineo Viola (Viola tineorum).

The NR is also characterized by an environmental heterogeneity that creates different habitat and ecological niches for many wildlife species. In fact NR houses $80 \%$ of regional animal species, including birds and wildlife (Giardina, 1977).

Among large mammals, the deer (Dama dama) and the wild boar (Sus scrofa) are present, both reintroduced within a few controlled areas. Other species present are the fox (Vulpes vulpes), the hare (Lepus corsicanus), the wild rabbit (Oryctolagus cuniculus), the wild cat (Felis silvestris), marten (Martes martes), the weasel (Mustela nivalis), the porcupine (Hystrix cristata) and the hedge-hog (Erinaceus europaeus).

Birdlife is very rich, including the blue tit (Parus caeruleus), the great tit (Parus major), the hoopoe (Upupa epops), the jay (Garrulus glandarius), the short toed treecreeper (Certhia toed) and the great spotted woodpecker (Dendrocopos major).

Among the predators, the golden eagle (Aquila chrysaetos) and the peregrine falcon (Falco peregrinus) have to be mentioned.

Inside the NR are present also several facilities, such as the Regional Centre for Wildlife Recovery "Ficuzza", located near the homonymous town center. It is managed by the Bird Protection Italian Association that, in addition to carry out service to wildlife distressed, houses a didactic room where movies and slide shows on the reserve can be viewed (LIPU, 2014).

Furthermore, Ethno-Anthropological Museum Godranopoli, Alpe Cucco mountain lodge and Val dei Conti mountain lodge are present inside the NR. 


\section{MATERIALS AND METHODS}

At the aim of evaluating how PES could contribute creating value for the local area, it has been taken into account Bosco Ficuzza, localized in the hillmountain Palermo area. Bosco Ficuzza is particularly well frequented both in summer and in winter from simple citizen, hiker groups, voluntary and other associations (Table 1).

The case study has been chosen in order to conform to the work aims and to find a solution to management problems of the detected area.

PES system originates from the consumer recognition of products or services offered by forests.

This awareness is related to the existing interconnections among the landscape and other activities present in the area. A greater measure of products or services offered by the forest should correspond to a greater consumer awareness of forest value.

In common mentality environmental resources are considered as public goods and not as products or services that have to be paid. So that these resources are perceived from the consumer, an efficacy communication policy is necessary, highlighting products or services utility.

The next step corresponds to recognize their efficiency. In order to guarantee goods results, the connection between products/services and the price to pay has to be clear. Paying for an environmental resource entails the reception of its value and subsequently consumers are obliged to pay those who contribute to the creation of these resources.

According to some authors (Santeramo et al., 2012; Sgroi et al., 2014b; 2014c; 2014d; 2014e; Testa et al., 2014b; Tudisca et al., 2013a; 2013b; 2013c; Everard and McInnes, 2013) forest landscape is considered an environmental resource that can originate flows when its value is defined by the connection with other values that increase its usefulness.

Table 1. Actors, products and services of the case study

\begin{tabular}{ll}
\hline Product/services offered & Landscape, leisure activities \\
\hline Localization & $\begin{array}{l}\text { Hillmountain Palermo } \\
\text { area (Sicily) }\end{array}$ \\
\hline Product/services sold & $\begin{array}{l}\text { Landscape management, } \\
\text { biodiversity, promotion } \\
\text { of natural beauty, } \\
\text { tourist accommodation }\end{array}$ \\
\hline Who buys? & citizens, tourists \\
\hline Who sells? & $\begin{array}{l}\text { State Forestry Corp, } \\
\text { agroforestry farm }\end{array}$ \\
\hline
\end{tabular}

Landscape, that represent geographical space modelled by man, culture, tradition and human capital represent resources on which PES can be applied.

Another fundamental element corresponds to the identification of buyers. The offered product is considered exclusive in function of its territorial connotation.

A considerable key to success is represented by the creation of network and synergy between local stakeholders (public administration, agro-forestry farms, etc.). In this phase the intervention of the public operator can be performed by means of certifications that guarantee products typicalness deriving from the reference area (Tudisca, 2014d).

Another important point for PES corresponds to the introduction of limits for utilization of resources (i.e. tax for mushrooms gathering, creation pay and display parking in order to avoid congestions). All the limits can become success guarantees because of confer greater value and quality.

Thus the introduction of limits and their reception reinforce PES, specially when limits are well illustrated.

The last key of PES success is represented by the introduction of new skills and the reintroduction of old ones (local artisan, food, wine and accommodations) at the aim of involving local population.

Furthermore, in the study economic and financial elements have been considered. After defining all the aspects involved for PES determination, as well as in other studies (Gios and Rizzo, 2013), we have considered 5 impact areas (financial, economic, institutional, social and identification) in which attributes have been defined (in order to create value for detected area by means PES), attributing a score ranging from 1 (minimum level of presence in the area) to 3 (maximum level).With regard to the financial area, ratio input/output, income and employment are present. In the economic area innovation and entrepreneurship are allocated. The institutional area corresponds to the constrains in the land use. In the social area we found culture and tradition, local participation new skills and networking processes. Ultimately, in the identification area recognition by consumers, local identification and destination of products or services. Analyzed critical factors have been questioned to local forestry operators and entrepreneurs.

Results have been showed by means of radar charts. Radar charts are widely used to explain the dynamics between interconnected variables or factors (AlWaer et al 2008; Bychholz et al., 2009; Bragança et al., 2010) and are also used in qualitative analysis (Aiello and Donvito, 2006), mainly to rank the attributes of the variables involved. 


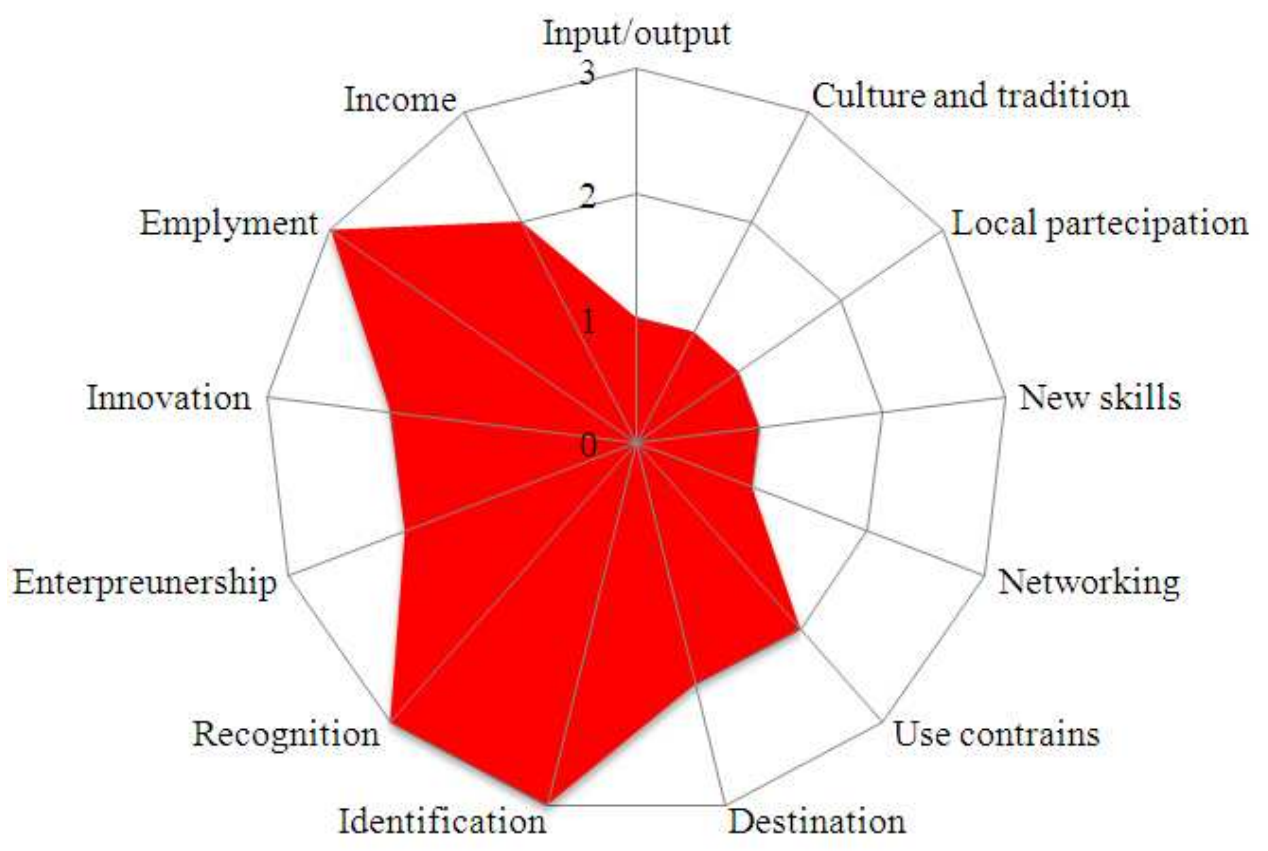

Fig. 2. Success elements emerging from the case studies analyzed

\section{RESULTS}

The analyzed NR highlights a high entrepreneurship level as a function of agricultural activity which is carried out in the area (viticulture, olive growing, livestock ac-tivity) and for the particular know-how.

Some traditional knowledge should be reintroduced. Today a good agritourism offer is present in the area by means of private entrepreneurs. Employment, recognition and identification showed higher values associated to the location site (Fig. 2). Destination, use constrains, innovation and entrepreneurship showed an average level.

This situation derives from income opportunities in the area. Networking, new skills, local participation, culture and tradition and input/output showed low values. This situation is due to the inability to create synergies and also to the infrequency of consumers/tourists with high spending power.

The PES creation passes certainly by a greater financial awareness. The payment of a tax for mushrooms gathering, parking or visits, becomes indispensable.

The environmental resource, if properly perceived by the consumer, represents an environmental service with high added value.

\section{CONCLUSION}

The case study of Bosco Ficuzza, aimed at creating a successful PES, is finalized at improving the management capacity and livability of the area. In order to build a PES, specific resources competences and local knowledge are required, as well as the possibility of introduc-ing successful management models.

It is also important to involve all local stakeholders (private companies, public administration, farmers, environmental associations). PES efficacy depends on the culture of potential consumers of products/services and also on the feedback processes in order to correct each ineffective or inefficient action. Environmental resources, local knowledge and business activities can represent the development driving force of these marginal areas that otherwise would be destined to human abandonment.

As demonstrated in the present paper, in the area lack the synergies between the different actors of the PES. The key to successful for the construction of new land supply is represented by building synergies between landscape and private activities, in order to offer new goods and services to all those who go to places that are often unknown. 


\section{ACKNOWLEDGEMENT}

This study is a result of the full collaboration of all the authors. However, Riccardo Squatrito wrote Introduction, Mario Foderà elaborated Payments for Environmental Services, Riccardo Testa wrote Case Study, Filippo Sgroi elaborated Materials and Methods, Anna Maria Di Trapani wrote Results, while Salvatore Tudisca wrote Conclusions.

\section{REFERENCES}

Agnese, C., F. D'Asaro, G. Grillone and A. Drago, 2008. Comparison of temperature data collected in urban and agricultural areas surrounding. Ital. J. Agrometeorol., 13: 48-49.

Aiello, G. and R. Donvito, 2006. L'evoluzione del concetto di lusso e la gestione strategica della marca. Un'analisi qualitativa delle percezioni sul concetto, sulla marca e su prodotto di lusso. Processing of International Conference: Le Tendenze del Marketing, Jan. 20-21, Venezia, Italy, pp: 1-16.

AlWaer, H., M. Sibley and L. Lewis, 2008. Different stakeholder perceptions of sustainability assessment. Architectural Sci. Rev., 51: 48-59.

Bragança, L., R. Mateus and H. Koukkari, 2010. Build-ing sustainability assessment. Sustainability 2: 2010-2023. DOI: 10.3390/su2072010

Brandt, P., D.J. Abson, D.A. Della Sala, R. Feller and H. von Wehrden, 2014. Multifunctionality and biodiver-sity: Ecosystem services in temperate rainforests of the Pacific Northwest, USA. Biol. Conserv., 169: 362-371. DOI: 10.1016/j.biocon.2013.12.003

Buchholz, T., E. Rametsteiner, T.A. Volk and V.A. Luzard-is, 2009. Multicriteria analysis for bioenergy systems assessments. Energy Policy, 37: 484-495. DOI: 10.1016/j.enpol.2008.09.054

Campbell, E.T. and D.R. Tilley, 2014. Valuing ecosys-tem services from Maryland forests using environ-mental accounting. Ecosyst. Services, 7: 141-151. DOI: 10.1016/j.ecoser.2013.10.003

Castellucci, L. and L. Delfini, 2006. L'economia delle foreste: strumenti di analisi e di intervento. Silvae, 4: 33-55.

Chomitz, K.M., E. Brenes and L. Constantino, 1999. Fi-nancing environmental services: The costa rican ex-perience and its implications. Sci. Total Environ., 240: 157-169. DOI: 10.1016/S00489697(99)00310-1
Costanza, R., R. D’Arge, R. De Groot, S. Farber and M. Grasso et al., 1997. The values of the world's ecosystem services and natural capital. Nature, 387: 253-260. DOI: 10.1038/387253a0

Cudlín, P., J. Seják, J. Pokorný, J. Albrechtová and O. Bas-tian et al., 2013. Chapter 24-forest ecosystem services under climate change and air pollution. Dev. Environ. Sci., 13: 521-546. DOI: 10.1016/B978-0-08-098349-3.00024-4

D’Asaro, F., G. Grillone and R.H. Hawkins, 2014. Curve Number: Empirical evaluation and comparison with Curve Number handbook tables in Sicily. J. Hydrol. Eng. DOI: 10.1061/(ASCE)HE.1943-5584.0000997

D'Asaro, F. and G. Grillone, 2012. Empirical investiga-tion of curve number method parameters in the Medi-terranean area. J. Hydrol. Eng., 17: 1141-1152. DOI: 10.1061/(ASCE)HE.1943-5584.0000570

Dasgupta, A.K. and D.W. Pearce, 1975. Analisi costibenefici, teoria e pratica. ISEDI, Milano.

Deal, R.L., B. Cochran and G. Larocco, 2012. Bundling of ecosystem services to increase forestland value and enhance sustainable forest management. Forest Policy Econom., 17: 69-76. DOI: 10.1016/j.forpol.2011.12.007

Di Trapani, A.M., F. Sgroi, R. Testa and S. Tudisca, 2014. Economic comparison between offshore and in-shore aquaculture production systems of European sea bass in Italy. Aquaculture. DOI: 10.1016/j.aquaculture.2014.09.001

Everard, M. and R. McInnes, 2013. Systemic solutions for multi-benefit water and environmental manage-ment. Sci. Total Environ., 461-462: 170179. DOI: 10.1016/j.scitotenv.2013.05.010

Federico, C., 2009. La flora della riserva naturale orien-tata di: Bosco della Ficuzza, Rocca Busambra, Bosco del Cappelliere e Gorgo del Drago. Priulla, Palermo.

Fedrowitz, K., J. Koricheva, S.C. Baker, D.B. Lindenmayer and B. Palik et al., 2014. Can retention forestry help conserve biodiversity? A metaanalysis. J. Applied Ecol. DOI: 10.1111/13652664.12289

Ferretti, F., P. Cantiani, I. De Meo and A. Paletto, 2014. As-sessment to soil protection to support forest planning: an experience in southern Italy. Forest Syst., 23: 44-51. DOI: 10.5424/fs/2014231-03345 
Gianguzzi, L. and A. La Mantia, 2004. Le serie di vege-tazione della riserva naturale orientata-bosco fi-cuzza, rocca busambra, bosco del cappelliere e Gor-go del drago, con allegata carta della vegetazione (scala 1: 20.000). Naturalista Siciliano, 28: $205-242$.

Giardina, G., 1997. La Vegetazione e la Fauna del Bosco di Ficuzza. In: Bosco di Ficuzza tra Storia e Natura, Giardina G. e Scarpulla A. (a cura di), Azienda Fore-ste Demaniali, pp: 29-46.

Gios, G. and D. Rizio, 2013. Payment for forest environmental services: A meta-analysis of successful el-ements. IForest, 6: 141-149. DOI: 10.3832/ifor0707-006

Gómez-Baggethun, E. and M. Ruiz-Pérez, 2011. Economic valuation and the commodification of ecosystem services. Prog. Phys. Geogr, 35: 613-628. DOI: 10.1177/0309133311421708

Grillone, G., G. Baiamonte and F. D'Asaro, 2014. Empirical determination of the average annual runoff co-efficient in the Mediterranean area. Am. J. Applied Sci., 11: 89-95. DOI: 10.3844/ajassp.2014.89.95

Grillone, G., C. Agnese and F. D’Asaro, 2012. Estimation of daily solar radiation from measured air temperature extremes in the mid-mediterranean area. J. Irrigat. Drainage Eng., 138: 939-947. DOI: 10.1061/(ASCE)IR.1943-4774.0000480

Grillone, G., C. Agnese and F. D'Asaro, 2009. Estimation of solar radiation in Sicily by daily data maximum and minimum temperature. Ital. J. Agrometeorol., 14: 84-85.

Klein, D., S. Höllerl, M. Blaschke and C. Schulz, 2013. The contribution of managed and unmanaged forests to climate change mitigation-a model approach at stand level for the main tree species in Bavaria. Forests, 4: 43-69. DOI: 10.3390/f4010043.

LIPU, 2014. Centro di re-cupero fauna selvatica Bosco di Ficuzza. Bird Protection Italian Association.

Liu, P. and R. Yin, 2012. Sequestering carbon in china's forest ecosystems: Potential and challenges. Forests, 3: 417-430. DOI: 10.3390/f3020417.

Mammuccini, M.G., 2004. Forest multifunctionality: new scenarios for research and innovation. Ital. J. Forest Mount. Environ., 59: 189-212.

Marshalek, E.C., B.S. Ramage and M.D. Potts, 2014. Integrating harvest scheduling and reserve design to im-prove biodiversity conservation. Ecol. Modell., 287: 27-35. DOI: 10.1016/j.ecolmodel.2014.04.022.
MEA, 2005. Ecosystems and Human Well-being: Synthesis. Island Press, Washington D.C.

Monarca, D., M. Cecchini, M. Guerrieri and A. Colantoni, 2009. Conventional and alternative use of biomasses derived by hazelnut cultivation and processing. Acta Horticul., 845: 627-634.

Muradian, R., E. Corbera, U. Pascual, N. Kosoy and P. May, 2010. Reconciling theory and practice: An alternative conceptual framework for understanding payments for environmental services. Ecol. Econom., 69: 1202-1208. DOI: 10.1016/j.ecolecon.2009.11.006

Pearce, D.W. and R.K. Turner, 1989. Economics of Natural Resources and Environment. Hempstead, Harvester and Wheatsheaf.

Pettenella, D., 2011. Servizi ecosistemici forestali e inte-grazione nelle politiche settoriali. Le risorse forestali nazionali e i servizi ecosistemici. Il ruolo delle istituzioni, Roma, Italy.

Pirard, R., R. Billé and T. Sembrés, 2010. Upscaling Payments for Environmental Services (PES): Critical issues. Tropical Conserv. Sci., 3: 249261.

Pirard, R., 2012. Market-based instruments for biodiver-sity and ecosystem services: A lexicon. Environ. Sci. Policy, 19-20: 59-68. DOI: 10.1016/j.envsci.2012.02.001

Prokofieva, I., S. Wundel and E. Vidale, 2012. Payments for environmental services: A way forward for mediterranean forests? EFI Policy Brief, 7: 16-16.

Santeramo, F.G., J. Di Pasquale, F. Contò, S. Tudisca and F. Sgroi, 2012. Analyzing risk management in mediterranean countries: The Syrian perspective. New Medit, 11: 35-40.

Sgroi, F., S. Tudisca, A.M. Di Trapani and R. Testa, 2014a. Economic evaluation of aquaculture invest-ments under conditions of risk and uncertainty in the Mediterranean sea. Am. J. Applied Sci., 11: 1727-1734. DOI: 10.3844/ajassp.2014.1727.1734

Sgroi, F., A.M. Di Trapani, R. Testa and S. Tudisca, 2014b. The rural tourism as development opportunity or farms. The case of direct sales in Sicily. Am. J. Agric. Biol. Sci., 9: 407-419. DOI: 10.3844/ajabssp.2014.407.419

Sgroi, F., A.M. Di Trapani, R. Testa and S. Tudisca, 2014c. Strategy to increase the farm competitiveness. Am. J. Agric. Biol. Sci., 9: 394400. DOI: 10.3844/ajabssp.2014.394.400 
Sgroi, F., S. Tudisca, A.M. Di Trapani, R. Testa and R. Squatrito, 2014d. Efficacy and efficiency of italian en-ergy policy: The case of PV systems in greenhouse farms. Energies, 7: 3985-4001. DOI: 10.3390/en7063985

Sgroi, F., A.M. Di Trapani, R. Testa and S. Tudisca, 2014e. Economic sustainability of early potato produc-tion in the Mediterranean area. Am. J. Applied Sci., 11: 1598-1603. DOI: 10.3844/ajassp.2014.1598.1603

SISEF. Multifunzionalità degli ecosistemi forestali mon-tani: Sfide e opportunità per la ricerca e lo sviluppo. SISEF.

TEEB, 2014. The economics of ecosystems and biodiversity: An interim report. European Commission, Brussels.

Testa, R., A.M. Di Trapani, M. Foderà, S. Sgroi and S. Tu-disca, 2014a. Economic evaluation of introduction of poplar as biomass crop in Italy. Renewable Sustainable Energy Rev., 38: 775-780. DOI: 10.1016/j.rser.2014.07.054

Testa, R., A.M. Di Trapani, F. Sgroi and S. Tudisca, 2014b. Economic analysis of process innovations in the man-agement of olive farms. Am. J. Applied Sci., 11: 1486-1491. DOI: 10.3844/ajassp.2014.1486.1491

Tirelli, M., 2009. Politica economica e fallimenti del mercato. Giampichelli Editore, Torino.

Tomao, A., F. Carbone, M. Marchetti, G. Santopuoli and C. Angelaccio et al., 2013. Forest, trees, externalities and ecosystem services. Ital. J. Forest Mount. Environ., 68: 57-73.

Tudisca, S., A.M. Di Trapani, F. Sgroi, R. Testa and G. Giamporcaro, 2014a. Role of alternative food networks in Sicilian farms. Int. J. Entrepreneurship Small Bus., 22: 50-63. DOI: 10.1504/IJESB.2014.062130

Tudisca, S., A.M. Di Trapani, F. Sgroi and R. Testa, 2014b. Organic farming and economic sustainability: The case of Sicilian durum wheat. Q. Access Success, 15: 93-96.

Tudisca, S., A.M. Di Trapani, E. Donia, F. Sgroi and R. Testa, 2014c. Entrepreneurial strategies of Etna wine farms. Int. J. Entrepreneurship Small Bus., 21: 155-164. DOI: 10.1504/IJESB.2014.059470

Tudisca, S., A.M. Di Trapani, F. Sgroi and R. Testa, 2014d. Economic evaluation of PDO introduction in Sicilian orange farms. Q. Access Success, 15: 99-103.
Tudisca, S., A.M. Di Trapani, F. Sgroi, R. Testa and R. Squatrito, 2013a. Economic analysis of PV systems on buildings in Sicilian farms. Renewable Sustainable Energy Rev., 28: 691-701. DOI: 10.1016/j.rser.2013.08.035

Tudisca, S., A.M. Di Trapani, F. Sgroi and R. Testa, 2013b. Marketing strategies for Mediterranean winer-ies competitiveness: The case of Pantelleria. Q. Access Success, 14: 101-106.

Tudisca, S., A.M. Di Trapani, F. Sgroi and R. Testa, 2013c. The cost advantage of Sicilian wine farms. Am. J. Applied Sci., 10: 1529-1536. DOI: 10.3844/ajassp.2013.1529.1536

Tudisca, S., F. Sgroi and R. Testa, 2011. Competitiveness and sustainability of extreme viticulture in Pantelleria Island. New Medit, 10: 57-64.

Turner, R.K., J. Paavola, P. Cooper, S. Farber and V. Jessamy et al., 2003. Valuing nature: lessons learned and future research directions. Ecol. Econom., 46: 493-510. DOI: 10.1016/S09218009(03)00189-7

Vidale, E., D. Pettenella, L. Secco and P. Gatto, 2012. Pa-gamenti per i servizi ambientali-Teoria, sistema giu-ridico e implementazione. Sherwood, 180: 21-26.

Wunder, S., 2014. Payments for environmental services: Some nuts and bolts. CIFOR Occasional.

Ximenes, F.A., B.H. George, A. Cowie, J. Williams and G. Kelly, 2012. Greenhouse gas balance of native forests in New South Wales, Australia. Forests, 3: 653-683. DOI: 10.3390/f3030653

Yan, L. and H. Tian, 2014. Assessing the effects of regional payment for watershed services program on wa-ter quality using an intervention analysis model. Sci. Total Environ., 493: 1056-1064. DOI: 10.1016/j.scitotenv.2014.06.096

Zanchi, G., S. Belyazid, C. Akselsson and L. Yu, 2014. Modelling the effects of management intensification on multiple forest services: A Swedish case study. Ecol. Modell., 284: 48-59. DOI: 10.1016/j.ecolmodel.2014.04.006 